\title{
EFFICACY OF MILKING OF THE CORD ON THE NEURODEVELOPMENTAL OUTCOME OF PRETERM BABIES
}

\author{
Lakshmi M. S1, Aparna Namboodiripad², V. C. Manoj ${ }^{3}$
}

1 Senior Resident, Department of Paediatrics, Jubilee Mission Medical College and Research Institute.

${ }^{2}$ Associate Professor, Department of Paediatrics, Jubilee Mission Medical College and Research Institute.

${ }^{3}$ Associate Professor, Department of Paediatrics, Jubilee Mission Medical College and Research Institute.

ABSTRACT

\section{BACKGROUND}

Although milking of cord has been shown to improve outcome of preterm babies in studies done in the west, very few Indian studies have been done so far. This is why this study was undertaken.

Objective- To assess immediate neurological outcome in preterms who received milking of the cord by neurological examination at discharge. To assess neurodevelopmental outcome at six months (corrected gestation) in surviving preterms who received milking of the cord by evaluating for developmental delay.

\section{MATERIALS AND METHODS}

This was a descriptive comparative study. All infants born in Jubilee Mission Medical College, Thrissur, during a 6-month period at less than 34 weeks of gestation who met the inclusion criteria were selected for this study, observed up to the age of 6 months and the effect of this intervention on the neurodevelopmental outcome was studied. Immediate neurological outcome was assessed by the number of neonatal deaths and neurological examination at discharge (Amiel-Tison Angles). They were followed up at 6 months by assessing neurodevelopmental outcome (Trivandrum Development Screening chart).

\section{RESULTS}

There was reduction in Amiel-Tison angle abnormalities and neurodevelopmental outcome at 6 months in the children whose mothers received milking of the cord, but the results were not statistically significant.

\section{CONCLUSION}

There is need for future randomised controlled trials at a multicentric level to provide further evidence in favour of administration of milking of cord for foetal neuroprotection in India.

\section{KEYWORDS}

Milking of Cord, Neurodevelopmental Outcome, Neonate.

HOW TO CITE THIS ARTICLE: Lakshmi MS, Namboodiripad A, Manoj VC. Efficacy of milking of the cord on the neurodevelopmental outcome of preterm babies. J. Evolution Med. Dent. Sci. 2018;7(10):1185-1188, DOI: $10.14260 /$ jemds/2018/271

\section{BACKGROUND}

Anaemia of prematurity is a common complication in very low birth weight babies, requiring neonatal red blood cell transfusions. The latter comes with various risks. Delaying cord clamping for at least 30 seconds results in a lower incidence of red blood cell transfusion, necrotising enterocolitis and intraventricular haemorrhage. ${ }^{1-10}$ However, delaying of cord clamping may impede neonatal resuscitation and increase neonatal hyperbilirubinaemia. ${ }^{3}$ Milking the umbilical cord towards the baby before clamping takes less than five seconds and so does not interfere with neonatal resuscitation and maybe of comparable benefit to cord clamping. ${ }^{11}$ Milking of the cord increases haematocrit at 36 to 48 hours of age. ${ }^{12}$ There is a paucity of data to support this practice. $^{13} \mathrm{~A}$ randomised controlled trial in Japan ${ }^{14}$ has reported a reduced need for neonatal red blood cell

'Financial or Other Competing Interest': None.

Submission 23-01-2018, Peer Review 17-02-2018,

Acceptance 23-02-2018, Published 05-03-2018.

Corresponding Author:

Dr. Aparna Namboodiripad,

Department of Paediatrics,

Jubilee Mission Medical College and Research Institute,

Thrissur-680005, Kerala, India.

E-mail: apnarel@gmail.com

DOI: $10.14260 /$ jemds $/ 2018 / 271$ transfusions, increased blood pressure in the first 12 hours of life and increased urine output in the first 72 hours of life. 15

Cerebral palsy (CP) is a group of disorders characterised by motor and/or postural dysfunction of a non-progressive nature commonly associated with cognitive impairment. The prevalence of $\mathrm{CP}$ is 2 to 2.5 per 1000 live births ${ }^{16}$ with principal risk factors ${ }^{17,18}$ being preterm birth $^{19-25}$ (particularly less than 34 weeks) and very low birth weight (less than 1500 g). ${ }^{26}$ Although, milking of cord has been suggested to improve neurological outcome and incidence of cerebral palsy in preterm babies in studies done in the West, very few Indian studies have been done so far. Hence, we undertook this study. The present study is to establish the feasibility and the effects of cord milking in preterm infants less than 34 weeks of gestational age.

\section{MATERIALS AND METHODS}

This was a descriptive comparative study done in a period of 18 months (Dec 2014 - May 2016). Eighty-three preterm babies of less than 34 weeks gestation, born at Jubilee Mission Hospital and admitted to Neonatal Intensive Care Unit during the period were selected for the study. It is the practise of certain gynaecologists to practise milking of the cord in preterm babies, while others do not undertake this practice. The preterm babies admitted to the NICU were divided into two groups depending on whether they received 
milking of cord or not and were recruited into the study after getting consent.

\section{Sample Size Calculation}

For a power of $80 \%$ with alpha error $5 \%$ assuming expected proportions with poor neurodevelopment outcomes in the cranial ultrasound positive and negative groups as P1 and P2, required minimum sample sizes were arrived at using the formula $\mathrm{n}=2(\mathrm{Z} 1-\alpha / 2+\mathrm{Z} 1-\beta) 2(\mathrm{P} Q)(\mathrm{P} 1-\mathrm{P} 2) 2$, where $\mathrm{Zk}$ is the $\mathrm{K}^{\text {th }}$ percentile value of Standard normal distribution, $\mathrm{Q} 1=(1-$ $\mathrm{P} 1), \mathrm{Q} 2=(1-\mathrm{P} 2), \mathrm{P}=(\mathrm{P} 1+\mathrm{P} 2) / 2$ and $\mathrm{Q}=(1-\mathrm{P})$. For $\mathrm{P} 1=50 \%$ and $P 2=20 \%$, about 40 patients each were required in the two comparison groups. Accordingly, expecting that half the high-risk patients will be with positive findings in cranial ultrasound, the minimum sample size required was 80 .

Accordingly, a minimum of 40 babies were consecutively enrolled in each group (milking done and milking not done), starting from the date of study-

1. Group A: Premature babies to whom milking of the cord was not done (41 babies).

2. Group B: Premature babies to whom milking of the cord was done (42 babies).

Monochorionic-diamniotic (MCDA) twin pregnancy, Severe Intrauterine growth restriction (IUGR) in antenatal scan $(<10$ th centile) and known case of hydrops foetalis were excluded from the study.

\section{Methodology}

After the caesarean section, the baby was placed near the mother's legs at or below the level of placenta and for the normal delivery was held below the level of placenta. About $20 \mathrm{~cm}$ length of the cord was held towards the placental side and the cord milked towards the baby at approximately 10 $\mathrm{cm} / \mathrm{sec}$ speed. The process was then repeated three times and the cord clamped and the baby was handed over to the neonatal team. Rest of the resuscitation was as per the standard guidelines.

Data was collected using prepared questionnaires by interview of parents, physical examination of babies, monitoring for development of complications and imaging techniques. Both the groups were compared regarding gestational age, gender, birth weight and the occurrence of Pregnancy Induced Hypertension (PIH), Gestational Diabetes Mellitus (GDM) and Premature Rupture of Membranes (PROM). Immediate neurological outcome was assessed by neurological examination (Amiel-Tyson ${ }^{27}$ Angles, Hammersmith neonatal neurological examination) at discharge and neuroimaging done in the first month of life. Routine cranial ultrasound study was done as per standard International guidelines on Day 0 - 3, Day 7 and Day 28 and subsequently to evaluate features of intraventricular haemorrhage or white matter injury, which are strongly corroborative for development of CP. In babies with abnormal cranial ultrasound findings, MRI brain was advised at corrected gestational age of 40 weeks to look for features of periventricular leucomalacia. All investigations were routinely done as per standard guidelines and no additional expenses were incurred to the patients on account of the study.
The babies were followed up at 6 weeks and further neurodevelopmental assessment was done during follow-up at 6 months of corrected gestational age using Amiel-Tison angles to detect tone abnormalities and using the Trivandrum Development Screening Chart (TDSC) 28 to detect developmental delay. Repeat neuroimaging was done in cases with abnormal findings 29 in the first imaging.

\section{Statistical Analysis}

Percentages were compared using Chi-square tests or Fisher's exact tests. Data were entered using Microsoft Excel and statistical analysis were done using IBM SPSS Statistics for Windows Version 21. P values less than .05 were considered for statistical significance.

Results on continuous measurements are presented on mean \pm SD (Min-Max) and results on categorical measurements are presented in Number (\%). Significance is assessed at $5 \%$ level of significance.

\section{RESULTS}

The baseline characteristics such as gestational age, gender distribution, birth weight distribution, pregnancy induced hypertension (PIH), Gestational diabetes mellitus (GDM) and premature rupture of membranes (PROM) of both the groups were comparable (Table 1)

Sex distribution in both the groups were also similar. There were more extremely low birth weight babies in the group which did not undergo milking. The number of mothers who had PIH was more in the group who did not undergo milking of cord, but this was not statistically significant ( $p$ value 0.748 , Pearson Chi-square test). More number of mothers who had GDM did not undergo milking of cord when compared to those who underwent milking. This difference was also not statistically significant ( $p$ value $=0.196$ ). The number of mothers who had PROM and Infection in both groups were similar.

When primary outcomes were compared in both the groups, it was found that $97.6 \%$ of preterms who underwent milking of cord survived when compared to $90.2 \%$ of those who did not undergo milking of the cord (Table 2). But this was not statistically significant (Fisher's exact test, $F=0.202$ ). Preterms who underwent milking of cord had less AmielTison angle abnormalities when compared to those who did not, but this was not statistically significant $(P$ value $=0.325)$.

Cranial Ultrasound abnormalities: Among babies who did not undergo milking, $34.1 \%$ had first cranial ultrasound abnormalities, but only $4.8 \%$ of babies who underwent milking had abnormalities. This was statistically significant (Pearson Chi-square test, $\mathrm{P}$ value $=0.001$ ). Second cranial ultrasound abnormalities were found in $41.5 \%$ of those who did not undergo milking of cord when compared to $9.5 \%$ of those who underwent milking of cord and this was statistically significant (Pearson Chi-square test, $\mathrm{P}$ value $=$ 0.001). The number of preterms who underwent milking had significantly less third cranial ultrasound abnormalities when compared to those who did not (Pearson Chi-square test, $\mathrm{P}$ value $=0.000$ ).

Developmental delay was found in $36.6 \%$ of those who did not undergo milking when compared to $26.2 \%$ in those who underwent milking. But this was not statistically significant, $\mathrm{P}$ value $=0.307$. 


\begin{tabular}{|c|c|c|c|c|c|c|}
\hline \multirow{3}{*}{ Variables } & \multirow{3}{*}{ Category } & \multicolumn{4}{|c|}{ Milking of Cord } & \multirow{3}{*}{$\begin{array}{c}\mathbf{P} \\
\text { Value }\end{array}$} \\
\hline & & \multicolumn{2}{|c|}{ Not Done (A) } & \multicolumn{2}{|c|}{ Done (B) } & \\
\hline & & $n=41$ & $\%$ & $n=42$ & $\%$ & \\
\hline \multirow{2}{*}{$\begin{array}{c}\text { Gestational } \\
\text { Age }\end{array}$} & & 21 & 51.2 & 32 & 76.2 & \multirow{2}{*}{0.0179} \\
\hline & $<32 \mathrm{~W}$ & 20 & 48.8 & 10 & 23.8 & \\
\hline \multirow{2}{*}{$\begin{array}{c}\text { Gender } \\
\text { Distribution }\end{array}$} & Male & 21 & 51.2 & 20 & 47.6 & \multirow{2}{*}{0.7429} \\
\hline & Female & 20 & 48.8 & 22 & 52.4 & \\
\hline \multirow{3}{*}{$\begin{array}{c}\text { Birth } \\
\text { Weight } \\
\text { Distribution }\end{array}$} & $>2.5 \mathrm{~kg}$ & 3 & 7.3 & 4 & 9.5 & \multirow{3}{*}{0.00176} \\
\hline & $1.5-2.5 \mathrm{~kg}$ & 16 & 39 & 31 & 73.8 & \\
\hline & $<1.5 \mathrm{~kg}$ & 22 & 53.6 & 7 & 16.7 & \\
\hline \multirow{2}{*}{$\begin{array}{c}\mathrm{PIH} \\
\text { Distribution }\end{array}$} & & 31 & 75.6 & 33 & 78.9 & \multirow{2}{*}{0.7481} \\
\hline & Yes & 10 & 24.4 & 9 & 21.4 & \\
\hline \multirow{2}{*}{$\begin{array}{c}\text { GDM } \\
\text { Distribution }\end{array}$} & $\mathrm{N}$ & 33 & 80.5 & 38 & 90.5 & \multirow{2}{*}{0.2268} \\
\hline & $\mathrm{Ye}$ & 8 & 19.5 & 4 & 9.5 & \\
\hline \multirow{2}{*}{$\begin{array}{c}\text { PROM } \\
\text { Distribution }\end{array}$} & & 31 & 75.6 & 31 & 73.8 & \multirow{2}{*}{0.8504} \\
\hline & Yes & 10 & 24.4 & 11 & 26.2 & \\
\hline
\end{tabular}

Table 1. Comparison of Baseline Characteristics

\begin{tabular}{|c|c|c|c|c|c|c|}
\hline \multirow{3}{*}{ Variables } & \multirow{3}{*}{ Category } & \multicolumn{4}{|c|}{ Milking of Cord } & \multirow{3}{*}{$\begin{array}{c}P \\
\text { Value }\end{array}$} \\
\hline & & \multicolumn{2}{|c|}{$\begin{array}{l}\text { Not Done } \\
\text { (A) }\end{array}$} & \multicolumn{2}{|c|}{ Done (B) } & \\
\hline & & $n=41$ & $\%$ & $n=42$ & $\%$ & \\
\hline \multirow{2}{*}{$\begin{array}{l}\text { Immediate } \\
\text { Outcome } \\
\text { Group }\end{array}$} & & 37 & 90.2 & 41 & 97.6 & \multirow[b]{2}{*}{0.202} \\
\hline & Not Survived & 4 & 9.8 & 1 & 2.4 & \\
\hline \multirow{2}{*}{$\begin{array}{c}1^{\text {st }} \text { Cranial } \\
\text { Ultrasound } \\
\text { Distribution }\end{array}$} & \begin{tabular}{|c|} 
No \\
Haemorrhage
\end{tabular} & 27 & 65.9 & 40 & 95.2 & \multirow[t]{2}{*}{0.0007} \\
\hline & Haemorrhage & 14 & 34.1 & 2 & 4.8 & \\
\hline \multirow{2}{*}{$\begin{array}{l}\text { 2nd Cranial } \\
\text { Ultrasound } \\
\text { Distribution }\end{array}$} & \begin{tabular}{|c|} 
No \\
Haemorrhage \\
\end{tabular} & 24 & 58.5 & 38 & 90.5 & \multirow[t]{2}{*}{0.0010} \\
\hline & Haemor & 17 & 41.5 & & 9.5 & \\
\hline \multirow{2}{*}{$\begin{array}{l}3^{\text {rd }} \text { Cranial } \\
\text { Ultrasound } \\
\text { Distribution }\end{array}$} & $\begin{array}{c}\text { No } \\
\text { Haemorrhage }\end{array}$ & 24 & 58.5 & 39 & 92.9 & \multirow[t]{2}{*}{0.0003} \\
\hline & Haemorrhage & 17 & 41.5 & 3 & 7.1 & \\
\hline \multirow[b]{2}{*}{$\begin{array}{c}\text { Amiel-Tison } \\
\text { Angle }\end{array}$} & \begin{tabular}{|l|} 
Normal \\
\end{tabular} & 22 & 53.7 & 27 & 64.3 & \multirow{2}{*}{0.3250} \\
\hline & Not & 19 & 46.3 & 15 & 35.7 & \\
\hline \multirow{2}{*}{$\begin{array}{c}\text { Developmental } \\
\text { Delay }\end{array}$} & No Delayed & 26 & 63.4 & 31 & 73.8 & \multirow{2}{*}{0.3073} \\
\hline & Delayed & 15 & 36.6 & 11 & 26.2 & \\
\hline
\end{tabular}

\section{DISCUSSION}

In our study, there was a significant increase in cranial ultrasound abnormalities in babies in the group that did not undergo milking. A retrospective meta-analysis of randomised trials was conducted by Rabe $\mathrm{H}$, which showed less incidence of intraventricular haemorrhage in the imaging of babies $(p=0.002)$ with delayed cord clamping. ${ }^{1} \mathrm{~A}$ systematic review and meta-analysis of the efficacy and safety of umbilical cord milking in full-term and preterm neonates found a reduced risk for intraventricular haemorrhage of all grades in infants assigned to the umbilical cord milking group. ${ }^{30}$

In our study, the neurodevelopmental evaluation at 6 months corrected gestational age showed that more (36.6\%) of those who did not undergo milking had developmental delay when compared to $(26.2 \%)$ those who underwent milking. But this was not statistically significant ( $\mathrm{p}$ value $=$ 0.307). Outcome after discharge from hospital was reported for one other small study (with 58 children), in which there were no significant differences between the groups in mean Bayley II scores at age seven months (corrected for gestation at birth). A recent retrospective study confirmed these results and demonstrated that umbilical cord milking as compared with immediate cord clamping also improved neonatal left ventricular diastolic function and stabilised neonatal cerebral oxygenation. ${ }^{11}$

\section{CONCLUSION}

In our study milking of umbilical cord did not reduce risk of neonatal deaths, Amiel-Tison angle abnormalities or neurodevelopmental delay at corrected gestation of 6 months. Cranial ultrasound abnormalities were significantly lowered in the group which underwent milking of cord. The limitations of our study were the small sample size and the timing of assessment of neurological development at 6 months of corrected gestational age (when allowance can be made for mild deviations from normal). Our study emphasises the need for large multicentric trials in India to study the neuroprotective effect of milking of the cord.

\section{ACKNOWLEDGEMENT}

We extend our sincere gratitude to faculty members of Jubilee Centre for Medical Research for editing this article.

\section{REFERENCES}

[1] Rabe H, Reynolds G, Diaz-Rossello J. A systematic review and meta-analysis of a brief delay in clamping the umbilical cord of preterm infants. Neonatology 2008;93(2):138-44.

[2] Rabe H, Diaz-Rossello JL, Duley L, et al. Effect of timing of umbilical cord clamping and other strategies to influence placental transfusion at preterm birth on maternal and infant outcomes. The Cochrane Database Syst Rev 2012;(8):CD003248.

[3] Aladangady N, McHugh S, Aitchison TC, et al. Infants' blood volume in a controlled trial of placental transfusion at preterm delivery. Pediatrics 2006;117(1):93-8.

[4] Strauss RG, Mock DM, Johnson KJ, et al. A randomized clinical trial comparing immediate versus delayed clamping of the umbilical cord in preterm infants: short-term clinical and laboratory endpoints. Transfusion 2008;48(4):658-65.

[5] Oh W, Fanaroff AA, Carlo WA, et al. Effects of delayed cord clamping in very-low-birth-weight infants. Journal of Perinatology 2011;31(Suppl 1):S68-S71.

[6] Kinmond S, Aitchison TC, Holland BM, et al. Umbilical cord clamping and preterm infants: a randomised trial. BMJ 1993;306(6871):172-5.

[7] Kugelman A, Borenstein-Levin L, Riskin A, et al. Immediate versus delayed umbilical cord clamping in premature neonates born $<35$ weeks: a prospective, randomized, controlled study. American Journal of Perinatology 2007;24(5):307-15.

[8] Mercer JS, Vohr BR, McGrath MM, et al. Delayed cord clamping in very preterm infants reduces the incidence of intraventricular hemorrhage and lateonset sepsis: a randomized, controlled trial. Pediatrics 2006;117(4):1235-42.

[9] Rabe H, Wacker A, Hülskamp G, et al. A randomised controlled trial of delayed cord clamping in very low birth weight preterm infants. European Journal of Pediatrics 2000;159(10):775-7. 
[10] Ultee CA, van der Deure J, Swart J, et al. Delayed cord clamping in preterm infants delivered at 34-36 weeks' gestation: a randomised controlled trial. Archives of Disease in Childhood-Fetal and Neonatal Edition. 2008;93(1):F20-3.

[11] Rabe H, Jewison A, Alvarez RF, et al. Milking compared with delayed cord clamping to increase placental transfusion in preterm neonates: a randomized controlled trial. Obstetrics \& Gynecology 2011;117(2 Pt 1):205-11.

[12] Erickson-Owens DA, Mercer JS, Oh W. Umbilical cord milking in term infants delivered by cesarean section: a randomized controlled trial. Journal of Perinatology 2012;32(8):580-4.

[13] Hosono S, Mugishima H, Fujita H, et al. Umbilical cord milking reduces the need for red cell transfusions and improves neonatal adaptation in infants born at less than 29 weeks' gestation: a randomised controlled trial. Archives of Disease in Childhood-Fetal and Neonatal Edition 2008;93(1):F14-9.

[14] Hosono S, Mugishima H, Fujita H, et al. Blood pressure and urine output during the first $120 \mathrm{~h}$ of life in infants born at less than 29 weeks' gestation related to umbilical cord milking. Archives of Disease in Childhood-Fetal and Neonatal Edition 2009;94(5):F328-31.

[15] Takami T, Suganami Y, Sunohara D, et al. Umbilical cord milking stabilizes cerebral oxygenation and perfusion in infants born before 29 weeks of gestation. The Journal of Pediatrics 2012;161(4):742-7.

[16] Vincer MJ, Allen AC, Joseph KS, et al. Increasing prevalence of cerebral palsy among very preterm infants: a population-based study. Paediatrics 2006;118(6):e1621-e6.

[17] Pharoah PO, Cooke T, Johnson MA, et al. Epidemiology of cerebral palsy in England and Scotland, 1984-9. Archives of Disease in Childhood-Fetal and Neonatal Edition 1998;79(1):F21-5.

[18] Drummond PM, Colver AF. Analysis by gestational age of cerebral palsy in singleton births in north-east England 1970-94. Paediatric and perinatal Epidemiology 2002;16(2):172-80.

[19] Stanley FJ, Watson L. Trends in perinatal mortality and cerebral palsy in Western Australia, 1967 to 1985 . BMJ 1992;304(6843):1658-63.
[20] Hagberg B, Hagberg G, Beckung E, et al. Changing panorama of cerebral palsy in Sweden. VIII. Prevalence and origin in the birth year period 199194. Acta Paediatrica 2001;90(3):271-7.

[21] Vohr B, Allan WC, Scott DT, et al. Early-onset intraventricular hemorrhage in preterm neonates: incidence of neurodevelopmental handicap. Semin Perinatol 1999;23(3):212-7.

[22] Vermeulen GM, Bruinse HW, de Vries LS. Perinatal risk factors for adverse neurodevelopmental outcome after spontaneous preterm birth. European Journal of Obstetrics \& Gynecology and Reproductive Biology 2001;99(2):207-12.

[23] Robertson PA, Sniderman SH, Laros RK, et al. Neonatal morbidity according to gestational age and birth weight from five tertiary care centers in the United States, 1983 through 1986. American Journal of Obstetrics and Gynecology 1992;166(6 Pt 1):1629-45.

[24] Kuban KC, Levitan A, Pagano M, et al. Maternal toxemia is associated with reduced incidence of germinal matrix haemorrhage in premature babies. J Child Neurol 1992;7(1):70-6.

[25] Lorenz JM, Wooliever DE, Jetton JR, et al. A quantitative review of mortality and developmental disability in extremely premature newborns. Archives of Pediatrics \& Adolescent Medicine 1998;152(5):42535.

[26] Himpens E, Van den Broeck C, Oostra A, et al. Prevalence, type, distribution and severity of cerebral palsy in relation to gestational age: a meta-analytic review. Developmental Medicine \& Child Neurology 2008;50(5):334-40.

[27] Amiel-Tison C, Grenier A. Neurological assessment during first year of life. New York: Oxford University Press 1986: p. 46-94.

[28] Nair MK, Nair GS, George B, et al. Development and validation of Trivandrum Development Screening Chart for children aged 0-6 years [TDSC (0-6)]. The Indian Journal of Pediatrics 2013;80 (Suppl 2):S24855 .

[29] Whitaker AH, Feldman JF, Van Rossem R, et al. Neonatal cranial ultrasound abnormalities in low birth weight infants: relation to cognitive outcomes at six years of age. Pediatrics 1996;98(4 Pt 1):719-29.

[30] Al-Wassia H, Shah PS. Efficacy and safety of umbilical cord milking at birth: a systematic review and metaanalysis. JAMA Pediatrics 2015;169(1):18-25. 